\title{
SUSTAINABLE SHAPING OF URBAN SPACES IN THE CONTEXT OF THE ENVIRONMENT
}

\author{
Joanna Agnieszka Pawłowicz' \\ 1 The Faculty of Geodesy, Geospatial and Civil Engineering, University of Warmia and Mazury in Olsztyn, \\ 10-724 Olsztyn, Heweliusza Str. 4, Poland, e-mail: jopaw@uwm.edu.pl
}

Received: 2017.09.01

Accepted: 2017.10.01

Published: 2017.11.01

\begin{abstract}
The natural environment is of great importance when it comes to developing a city, as it shapes its spaces, defines its roles and performs climatic and protective functions. Industrialization often requires removing landscape obstacles and vegetation to erect new buildings. An urban planner should be aware of the borders that must not be crossed. Designing new streets and buildings should follow a sustainable growth pattern, if the city landscape and its climatic conditions are to improve for the generations to come. This paper discusses the aspects of planning and managing urban spaces in such a way so as to provide their users with healthy and comfortable living conditions. The paper is based on a survey conducted to gather the opinions of members of a city community on the environment in which they live.
\end{abstract}

Keywords: city landscape, green enclaves, green roofs, social participation

\section{INTRODUCTION}

Urban spaces are shaped by many factors, especially the human needs. In this way, cities were created and managed the needs of their residents for centuries. The functions of their particular parts were carefully planned in advance in order to most effectively use the existing landscape features and natural resources. Therefore, fortresses were built on hills and in river bends to provide effective defence against invaders. Apart from hampering the access to cities, rivers performed another important function, namely, they provided the city residents with water. A modern city has buildings, technical infrastructure, roads and spaces designed in such a way so as to provide its inhabitants with optimal living and working conditions. Urban planners aim at making the most out of the existing environmental features to increase the attractiveness of cities to potential new residents.

Urban spaces should be designed in a balanced way. It means that planning and changes should be managed to satisfy the needs of the present and future generations. To this end, plan- ning should be a long-term process and embrace particular development objectives, i.e. economic, social and ecological.

However, the natural environment is frequently ignored by urban planners, and the city greenery is not given enough consideration, although the existing legislation (e.g. the Planning and Zoning Act [Act of 27 March 2003], the Environment Protection Act [Act of 16 April 2004] or the decree on the technical conditions to be met by buildings and their situation [Decree of the Minister of Infrastructure of 12 April 2002], as well as the local law (e.g. local zoning plans) contain provisions related to greenery and biologically active areas. This legislation recommends that the natural resources be used and the city spaces be shaped so as to allow the people and nature to coexist.

\section{URBANIZED SPACES AND THE NATURAL ENVIRONMENT}

The ecological aspects of designing cities are related to maintaining a certain balance, especial- 
ly where the spatial development of a city, nature and the quality of human life come together. The concept of a green building is closely related not only to buildings and their application, but also to developing their surroundings by creating ecologically active areas. Vegetation and landscape are an important part of developing the land surrounding the residential estates [Chmielewski 2001]. If designed properly, greenery has a positive impact on people's well-being and comfort of living; carefully designed and adapted to the existing landscape, it also has an aesthetic effect, irrespective of its form, be it a single tree, a square, park or forest.

Ecology in urban planning enables a city to breathe. Urbanized areas are comprised of different types of urban fabric and a network of roads and streets where exhaust and other hazardous gases concentrate. High residential density hampers air exchange, resulting in the formation of smog. If well designed, a system of streets may be naturally aired out (Fig. 1). This is possible by creating open spaces and wind corridors allowing the air to flow from the green or forested areas inside or outside a city deep into the urban fabric [Gnatowska 2013,Laskowski 1987].

Another good solution for the residential areas is to plant low and high greenery near buildings, squares and passages. It is not only aesthetically pleasing but also isolates the buildings located in its vicinity from noise and exhaust gases (Fig.2). In addition, it plays a recreational role and integrates industrial buildings with nature, making the cityscape more attractive and benefiting the wellbeing of the society [Pawłowicz, Bundz 2014].
Unfortunately, when designing the already urbanized spaces, a planner cannot completely ignore the existing system of streets and quarters. This is particularly true about the city centre. Moreover, the greenery located there, often of historical value, is at risk of being reduced or removed altogether only because it happens to grow in an attractive location [Pęski 1999]. Such areas are also attractive to businesses and developers. The city authorities are often tempted to sell them, as their price is usually very high due to their location and the infrastructure existing nearby. This is why these areas do not offer much space to design a square or a lawn, let alone a park. The modern technologies, though, allow for applying other forms of city greenery. In such cases, covering buildings with horizontal and vertical greenery is a good solution. In addition to being biologically active and looking nice, green walls and roofs play a climate-forming and retention functions. However, they primarily improve the city landscape and add to the city climate (Fig. 3 ). Vegetation on buildings not only cleans but also moistens and cools the air. The greenery covering buildings prevents them from accumulating too much heat during the day. As a result, they do not emit excess heat in the evening (the so-called oven effect) [Baumann 1991].

Green roofs are also very practical and ecological as they require installation of rainwater tanks, which can also be used e.g. to flush toilets (Fig. 4). Such solutions benefit both the urban landscape and the environment.

Greenery allows for the proper airing out of the city, ensures optimal moisture level and im-

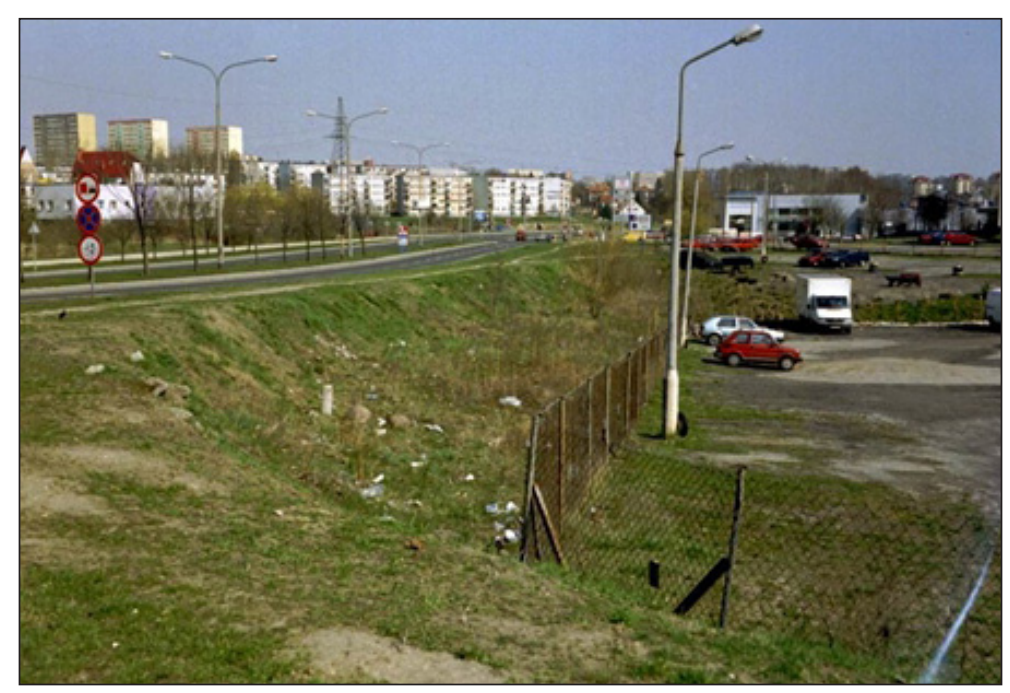

Fig. 1. Olsztyn - Obrońców Tobruku street - ,wind tunnel” (author’s photo) 


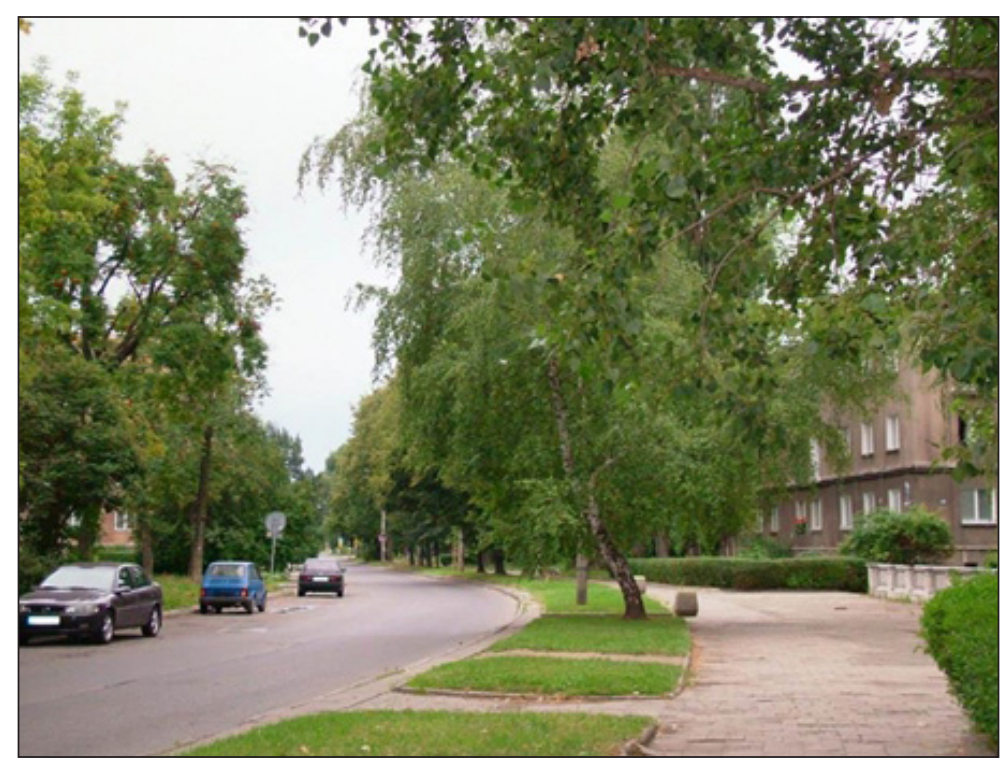

Fig. 2. Cracow - Nowa Huta - greenery isolating a local street

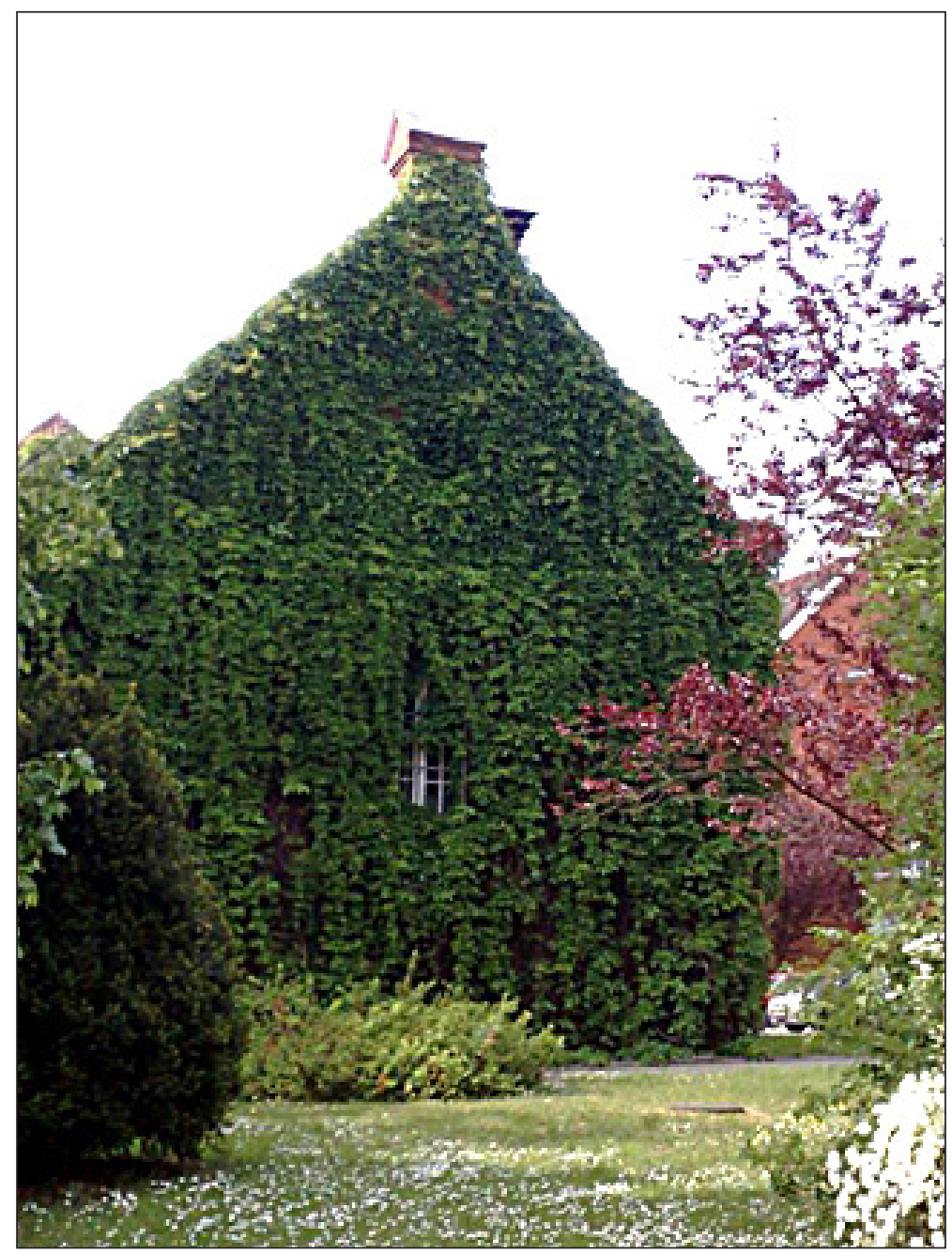

Fig. 3. Olsztyn - University Campus - façade of a historical building covered with Virginia Creeper 


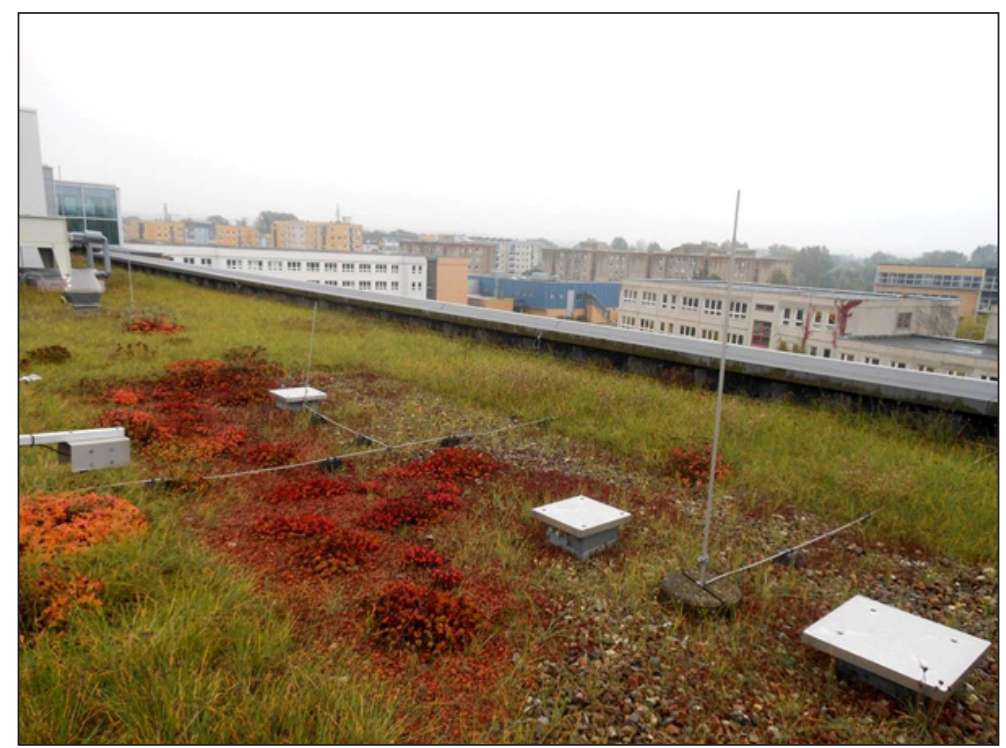

Fig. 4. Neubranderburg, Germany - the roof of the Hochschule building with a rainwater system

proves the condition of soil and water. Greenery helps to keep the soil stable and makes it resistant to erosion. The root system stabilizes the soil and allows rainwater to be quickly absorbed from the surface. It also prevents local floods, especially in the areas located in depressions.

\section{SURVEY}

In 2016, a survey was conducted among the residents of the city of Olsztyn, related to the quality of life in the city. A survey of this kind is a very good method of obtaining information about people's preferences [Pawłowicz, Szafranko 2014]. The respondents were asked, among other things, to evaluate the attractiveness of the city spaces and their symbiosis with the nature. Olsztyn is abundant in different forms of nature. It boasts app. 2,500 ha of forests and 11 lakes, all located within the city's borders. The residents of Olsztyn have no reason to complain about the lack of nature in the city. One could actually go so far as to say that it is the nature that shapes the city. The lack of greenery is limited only to small parts of the city, mainly the districts erected after the Second World War and those built at the turn of the $21^{\text {st }}$ century.

The respondents were asked e.g. to evaluate the amount of greenery in particular estates. Most of them agreed that the district of Nagórki has the least greenery. The district, built between the 1970s and 1990s, is comprised mainly of concrete apartment buildings. Back then, in order to meet the growing demand for the living space, apartment buildings were erected on a mass scale, with no regard for the environment. Their appearance did not improve the existing landscape, to say the least. The high density of buildings leaves little space for green enclaves. The continually growing number of cars makes the situation even worse - there are not enough parking lots. As a result, cars are parked almost everywhere.

On the other hand, the respondents agreed that the city authorities and estate administrators are making an effort to improve the situation. More and more green enclaves and playgrounds are being created, giving the residents the opportunity to interact with nature.

The Nad Jeziorem Długim and Dajtki districts were found to be the most abundant in greenery, which was described as being taken good care of. The residents of these districts appreciate having access to Lake Długie and Lake Ukiel. The vicinity of the City Forest constitutes a great advantage.

The Nad Jeziorem Długim district is situated on the edge of the forest, adjacent to the lake. The district features mainly houses and small apartment buildings, the only exception being three high-rise (11 floors) buildings erected in late 1970s. Most of the 2-4-storey buildings date back to the 1920s, the time when Olsztyn was part of East Prussia. Each building has a nice front- and backyard with a view on the forest or the lake. The district is a conservation area, which means that each new building erected there must conform to the existing style and landscape. 
The Dajtki district was built between 1970s and 1980s. It is located on an elevation overlooking the nearby forest and Lake Kortowskie. The driveways were designed not to interfere too much with the terrain, which also decreased the costs of earthworks. The land parcels are neat.

The major concern at the moment is the act passed on $1^{\text {st }}$ January 2017 [Journal of Laws of 2016, item. 2249] allowing land owners to cut the trees growing on their land without a permit. In consequence, many owners have cut down the trees that once were part of the district's landscape.

The residents of Zatorze also spoke very highly of their district, which. mainlyfeatures 2-4-storey buildings erected before the Second World War and afterwards. It is abundant in greenery, which, however, the respondents believe is not being taken good care of. They indicate that most of the trees need special treatment.

The districts of Dajtki and Nad Jeziorem Dhugim ale located in the eastern part of the city. The roads running through them also serve as air corridors. The wind rose for Olsztyn indicates that most of the air enters the city from this direction. The balanced cityscape of Olsztyn requires its authorities to preserve these air corridors to clean the air in the city.

\section{SUMMARY}

The natural environment is undoubtedly an important factor having an influence on shaping the city spaces. Urbanized areas are comprised of different types of fabric: industrial, commercial and residential. The city infrastructure must be integrated with greenery to provide the residents living or working in a given area with the access to the natural environment.

Urban spaces undergo continuous changes resulting from the changing needs of city dwellers. In many cities, modern buildings have pushed the nature out of the city. Luckily, the fashion for ecological lifestyle makes people expect a city landscape made up not only of concrete, steel, glass or asphalt but also shaped by nature. Let us then hope that trees and bushes will not disappear from cities and that architects will become more eager to use natural materials such as wood or stone to make the city spaces more aesthetically pleasing and nice to hang out in.

Urban planners must also make sure that new buildings are situated in such a way so as to allow the free movement of air between them. This will benefit both whole buildings and individual apartments. In the age of smog, properly shaped city spaces will let city residents breathe clean air. Sustainable shaping of the city spaces in a symbiosis with the natural environment will have a positive effect on the human health. It will also preserve the biological diversity and protect cities against flooding.

\section{REFERENCES}

1. Baumann Rudi, 1991, Domy w zieleni, Warszawa, Arkady

2. Chmielewski Jan, M., 2001, Teoria urbanistyki w projektowaniu i planowaniu miast, Warszawa, Oficyna Wydawnicza Politechniki Warszawskiej,

3. Decree of the Minister of Infrastructure of 12 April 2002 on the technical conditions to be met by buildings and their situation, Journal of Laws of 2002 no. 75 , item 690

4. Gnatowska Renata, 2013, Planowanie terenów zabudowanych w zgodzie $\mathrm{z}$ zasadami zrównoważonego rozwoju z zastosowaniem metod modelowych, Inżynieria Ekologiczna, 33, 35-40.

5. Laskowski Leszek, 1987, Wybrane zagadnienia fizyki miasta. Centralny Ośrodek Informacji Budownictwa

6. Pawłowicz Joanna A., Bundz Edyta, 2014, Use of woodland greenery for recreational purposes, Scientific Review of Physical Culture, 4/3, 145-150

7. Pawłowicz Joanna A., Szafranko Elżbieta, 2014, Rola partycypacji społeczeństwa w kształtowaniu lasów miejskich jako czynnika zrównoważonego i ekologicznego projektowania przestrzeni zurbanizowanej, Logistyka, 6, 12924-12935

8. Pęski Wojciech, 1999, Zarządzanie zrównoważonym rozwojem miast, Warszawa, Arkady,

9. The Environment Protection Act of 16 April 2004 Journal of Laws of 2004, no. 92, item 880,

10. The Planning and Development Act of 27 March 2003, Journal of Laws 2003 no. 80 item 717,

11. Ustawa $z$ dnia 16 grudnia 2016 r. o zmianie ustawy o ochronie przyrody oraz ustawy o lasach, Dz. U. Poz. 2249 